\title{
PERFORMA PANEL SURYA 2 X 50 WP PADA MESIN PANEN PADI MINI DUA LAJUR
}

Herdi Susanto

Tenaga Pengajar (Dosen) Universitas Teuku Umar Jurusan Teknik Mesin herdisusanto@utu.ac.id

Herri Darsan

Tenaga Pengajar (Dosen) Universitas Teuku Umar Jurusan Teknik Mesin herri.darsan@utu.ac.id

Mukhlizar
Tenaga Pengajar (Dosen)
STAIN Tengku Dirundeng
Pusat Teknologi Infromasi \& Komunikasi
mukhlizar@staindirundeng.ac.id

Nuzuli Fitriadi

Tenaga Pengajar (Dosen) Politeknik Aceh Selatan Program Studi Teknik Mesin nuzuli@poltas.ac.id
Rice harvesting machines that can be operated in swampy, peatland, narrow and can be operated and maintained by farmers, can be considered for design, some previous research has been carried out, including a two-lane mini rice harvester with a performance of 20.33 hours per hectare and has been in manufacturing and in performance tests. Experimental studies on engine performance were carried out in this research. This research uses $2 \times 50$ watt peak polycrystalline solar panels connected to a 12 volt 45 AH battery, the battery will drive a 50 watt electric motor. Current and voltage measurements are carried out on the solar panel and battery when in condition, first the solar panel is connected to the battery and not connected to the electric motor, the second solar panel is connected to the battery and connected to the electric motor, the three solar panels are not connected to the battery and the battery is connected to electric motor. The results of the first condition study indicate that the electric current will be more stable using a new battery, when compared to using a battery in the previous study. The second condition was that the performance of the two-lane mini rice harvester increased by 50\% when compared to the performance of an electric motor using a battery that was not connected to a solar panel. The third condition shows the performance of the electric motor has increased by up to $300 \%$ when compared with the results of previous studies, it is estimated that the electric motor will continue to rotate for up to 8-10 hours

Keywords: Solar Panel; Electric Motor; Battery Performance; Mini Rice Harvester

\section{PENDAHULUAN}

Alternatif penerapan alat panen padi mini diperlukan untuk petani sawah dperlukan, terutama alat bantu panen padi yang mampu dioperasikan sendiri oleh petani dan mampu diperbaiki oleh bengkel-bengkel industri kecil dan menengah didaerah perdesaan setempat [1-2], sehingga kinerja petani dapat ditingkatkan dalam hal produksi gabah, juga kriteria alat bantu yang dapat diaplikasikan pada area sawah lahan kecil dan sempit [3], rawa gambut serta bobot mesin relatif lebih ringan [4-5] , dengan biaya perawatan relatif murah dan sederhana dalam pengoperasioan [6-8]. Alat bantu panen padi dua lajur dengan bobot $65,26 \mathrm{~kg}$ yang telah difabrikasi dan diuji serta hasil penelitian menunjukkan bahwa alat bantu tersebut telah berfungsi dengan baik pada kecepatan panen 20,33 jam perhektar [9] penelitian tersebut merekomendasikan agar dilakukan kajian eksperimen terhadap kemampuan sistem panel surya untuk menggerak motor listrik.

Optimalisasi daya baterai yang yang digunakan untuk menggerakkan motor listrik telah dilakukan pada penelitian sebelumnya [10-11] menggunakan dua panel surya sebagai sumber energi, dimana kondisi luaraan tegangan luaran dan arus listrik pada situasi baterai dalam keadaan tidak terhubung dan terhubung, dimana jika panel surya tidak terhubung ke baterai kisaran tegangan berada pada posisi rata-rata 20,5 volt dan jika terhubung ke baterai tegangan luaran panel surya berkisar pada 14,45 volt . Kondisi grafik luaran arus listrik pada baterai ketika dilakukan pengisian dengan menggunakan panel surya 2 × 50 wp, dimana fluktuasi terjadi cukup besar dari pukul 11.00-14.00 WIB dan ini diperkirakan dikarenakan kinerja baterai yang digunakan dalam penelitian sebelumnya kurang maksimal dalam penyimpanan arus listrik.

Pengisian daya baterai menjadi kurang maksimal, jika dibandingkan dengan hasil perhitungan secara teoritis menyatakan bahwa panel surya akan mampu mengisi baterai penuh dalam waktu 5.4 jam dan baterai 
mampu menggerakkan motor listrik 50 watt selama 10,82 jam [5,10], Kajian lebih lanjut terhadap kemampuan sistem panel surya pada mesin panen padi mini untuk menggerak motor listrik 50 watt dengan menggunakan baterai baru dan baterai pada penelitian sebelumnya sebagai pembanding dilakukan pada penelitian ini, yang bertujuan untuk menentukan penyebab fluktuasi grafik luaran arus listrik dan juga untuk mengukur kemampuan kinerja baterai baru untuk menggerakkan motor listrik.

\section{METODE DAN BAHAN}

\subsection{Peralatan Penelitian}

Penelitian menggunakan peralatan utama dan pendukung yaitu, 1 (satu) Unit mesin panen padi mini dua lajur dengan panel surya 2 x $50 \mathrm{wp}$, ampermeter, stopwatch, voltmeter dan alat pendukung penelitian lainnya. Objek penelitian utama pada penelitian ini ditunjukkan pada Gambar 1 Posisi panel surya horizontal disesuaikan dengan rangka kontruksi mesin dengan pertimbangan lokasi penelitian berada sekitar garis eduator [12]

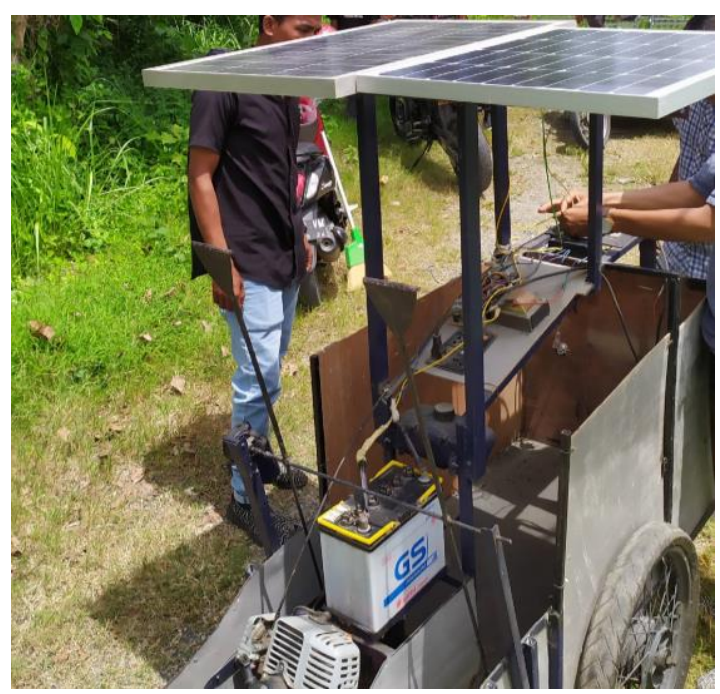

Gambar 1. Objek penelitian utama mesin panen padi mini dua lajur

\subsection{Diagram Alir Penelitian}

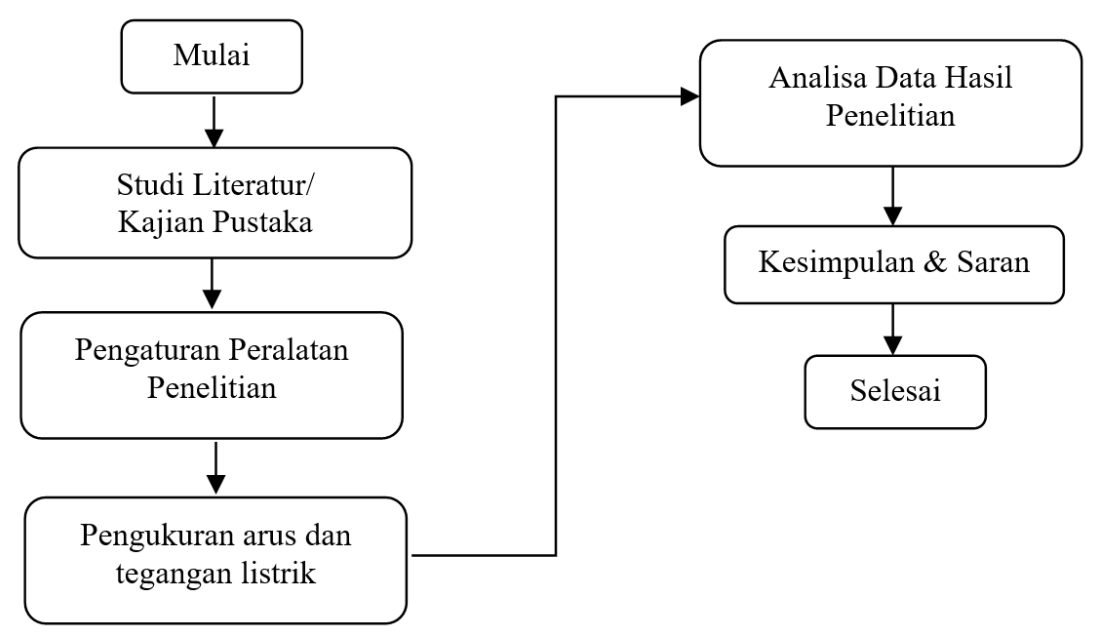

Gambar 2. Diagram Alir Penelitian 


\subsection{Pengaturan Peralatan Penelitian}

Pengaturan peralatan penelitian dilakukan sebelum dilakukan pengukuran dan pengambilan data penelitian, proses ini dilakukan agar hasil data pengukuran yang didapatkan dapat dipercaya dan memiliki nilai keakuratan, proses pengaturan penempatan posisi peralatan penelitian dan setting jalur instalasi jaringan listrik pada mesin panen padi disetting untuk membali untuk memastikan tidak ada yg salah dan kabel tidak rapat atau longgar [13], proses pengaturan peralatan penelitian ditunjukkan pada Gambar 3.

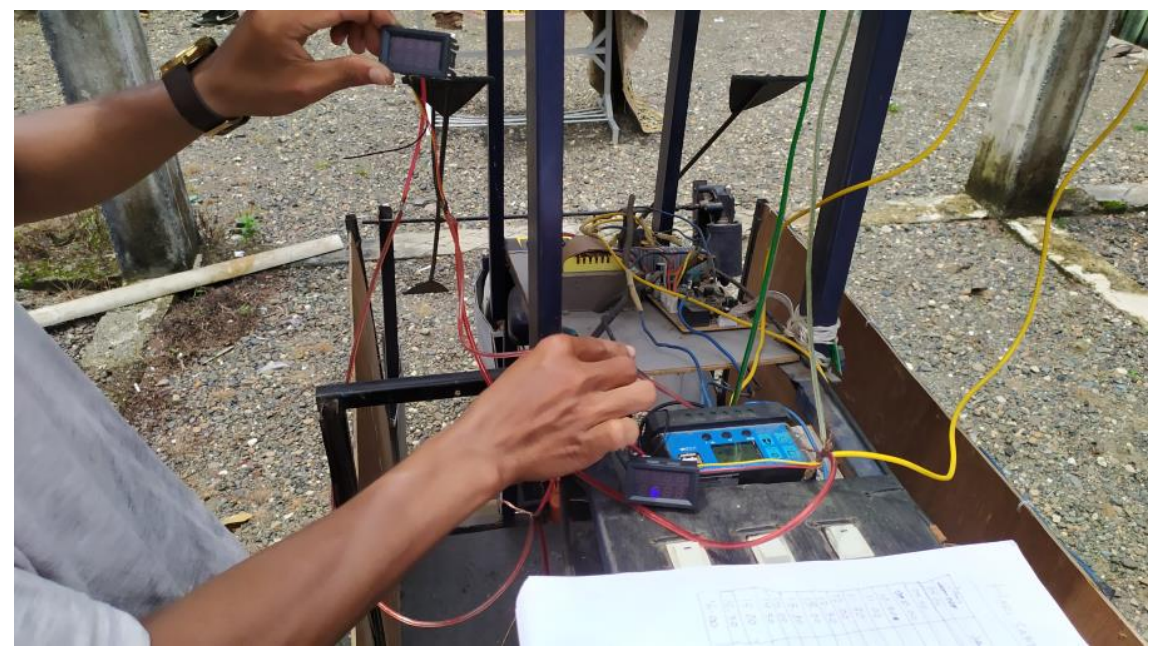

Gambar 3. Pengaturan peralatan penelitian pada mesin panen padi mini

Rangkaian instalasi jaringan listrik yang digunakan pada mesin panen padi mini dua lajur, diatur mengikuti skema pengaturan perangkat komponen yang terdiri dari panel surya polikristal (polycrystalline) 2 x $50 \mathrm{wp}$, kontroler panel surya 12/24 volt $30 \mathrm{~A}$, baterai 12 volt $45 \mathrm{AH}$ asam sulfat (H2SO4)[14], dan motor listrik 50 watt. Skema rangkaian tersebut ditunjukkan pada Gambar 4.

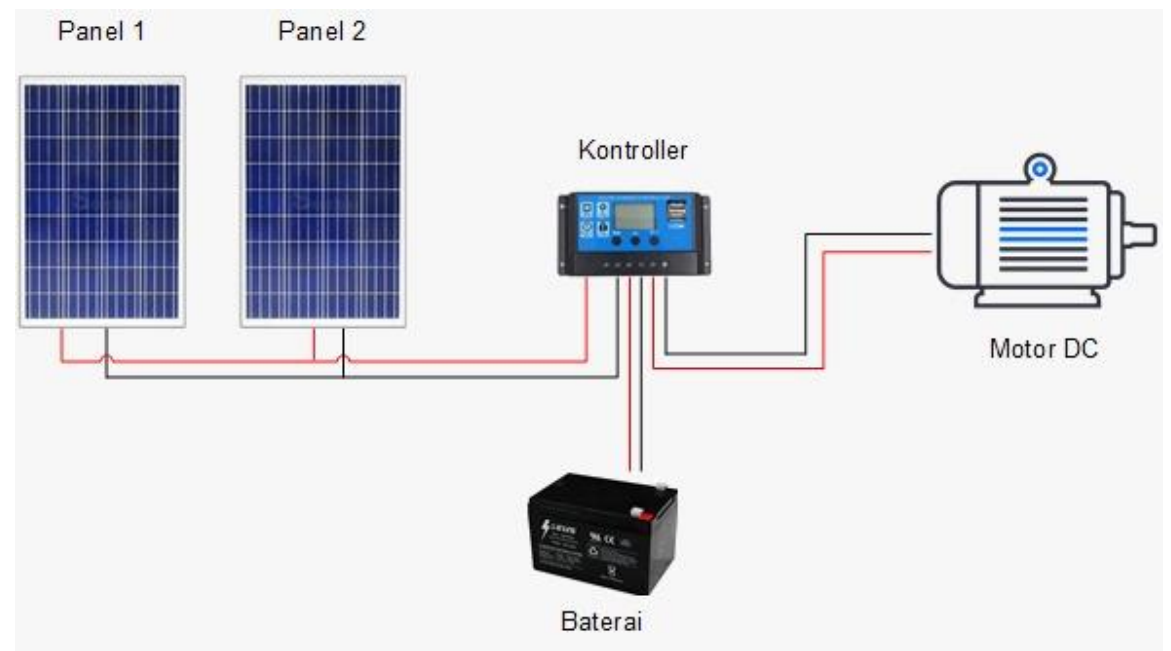

Gambar 4. Skema instalasi rangkaian komponen mesin panen padi dua jalur

Pengukuran luaran arus dan tegangan listrik pada penelitian ini dilaksanakan pada tiga kondisi pengaturan untuk komponen panel surya, baterai dan motor listrik yaitu kondisi pertama yaitu panel surya terhubung ke baterai dan tidak terhubung ke motor listrik, kondisi kedua yaitu panel surya terhubung ke baterai dan terhubung ke motor listrik, kondisi ketiga yaitu panel surya tidak terhubung ke baterai dan baterai terhubung ke motor listrik 


\section{HASIL DAN DISKUSI}

\subsection{Panel Surya Terhubung ke Baterai dan Tidak Terhubung ke Motor Listrik}

Pada penelitian berikutnya dilakukan pengukuran arus listrik lanjutan, dikarenakan pada penelitian sebelumnya grafik arus listrik yang mengalami fluktuasi sangat besar dari pukul 11.30 WIB hingga pukul 14.00 WIB [11]. Penelitian dilakukan dengan mengganti unit baterai 12 volt 45 AH dengan baterai yang baru, grafik hasil pengukuran tersebut menunjukkan arus listrik yang dihasilkan dari pengisian baterai dengan menggunakan 2 x 50 wp relatif stabil. Ini ditunjukkan pada Gambar 5 .

Hasil yang ditunjukkan pada Gambar 8 dapat dikatakan bahwa umur pemakaian baterai akan mempengaruhi arus listrik baterai dari pengisian dengan menggunakan panel surya, dimana terlihat bahwa arus listrik pada baterai baru terlihat lebih stabil arus listrik yang masuk ke baterai dengan rata-rata arus listrik yang masuk 500mA. Dibandingkan dengan baterai yang digunakan pada penelitian sebelumnya akan mengalami fluktuasi arus listrik yang cukup tinggi (mencapai $3000 \mathrm{~mA}$ ) ketika arus listrik dari panel surya mengisi baterai, ketidakstabilan ini disebabkan karena intesitas cahaya matahari pukul $11.00-14.00 \mathrm{WIB}$ memiliki intensitas cahaya matahari tertinggi, beberapa penelitian menyatakan hal tersebut [15-17] sehingga baterai yang digunakan pada penelitian sebelumnya sudah tidak maksimal menyimpan arus listrik dari panel surya.

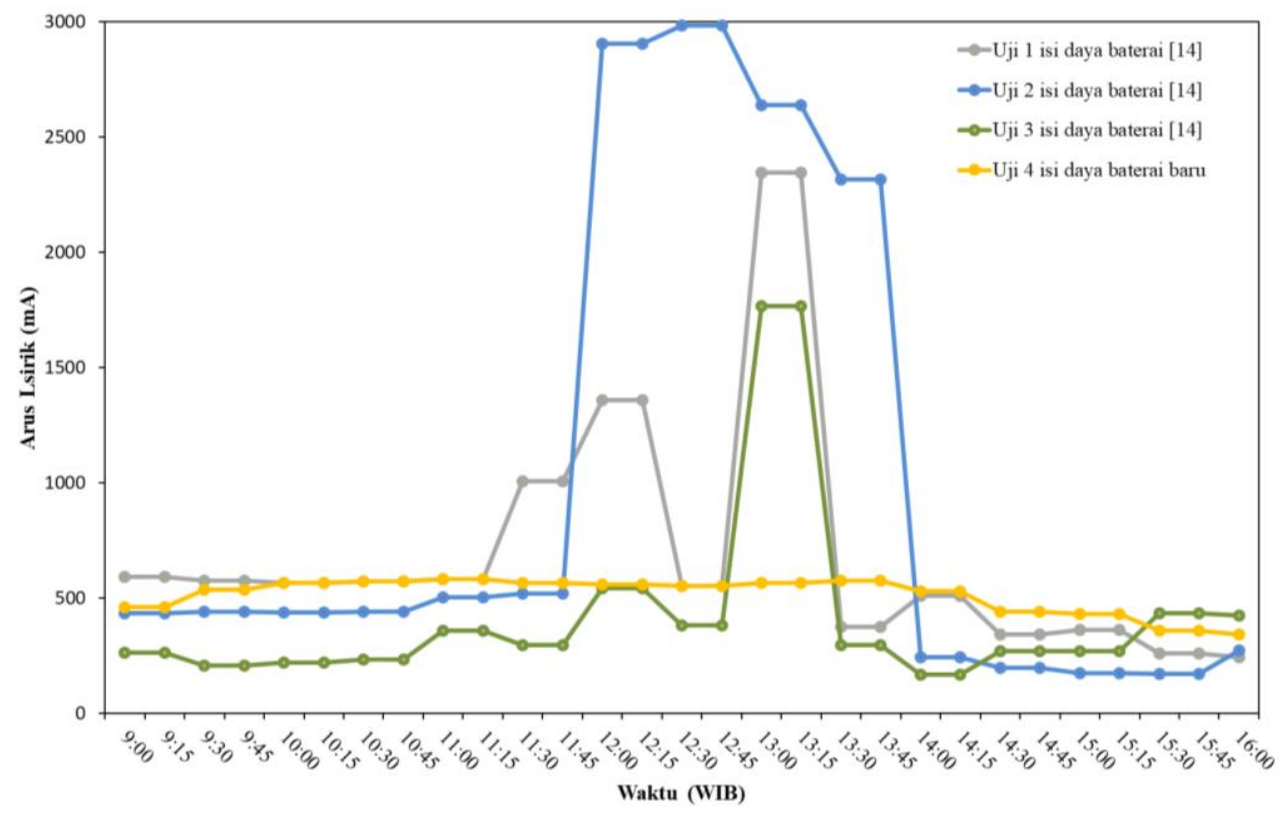

Gambar 5. Perbandingan arus pengisian daya untuk baterai penelitian sebelumnya dan baterai baru

Setelah fase fluktuasi ini berakhir pukul 14.00 WIB, maka arus listrik ketika pengisian daya baterai akan kembali normal terjadi, tetapi terjadi penurunan arus listrik berkisar $30 \mathrm{~mA}$ dari kondisi awal pengisian daya pada pukul 11.00 WIB. Ini berlaku baik untuk penelitian sebelumnya, maupun untuk penelitian yang dilakukan dengan menggunakan baterai baru $12 \mathrm{~V} 45 \mathrm{AH}$.

\subsection{Panel Surya Terhubung ke Baterai dan Terhubung ke Motor Listrik}

Perbandingan antara data luaran panel surya 2 x 50 wp dalam keadaan mengisi baterai 12 volt 45 AH dan kondisi baterai tidak terhubung ke panel surya, baterai terkoneksi dengan motor listrik, serta data peneltian sebelumnya yaitu kondisi baterai terhubung ke panel surya telah dilakukan tiga kali pengukuran luaran arus listrik. Kondisi tersebut dipaparkan dalam grafik yang ditunjukkan pada Gambar 6.

Gambar 6 menunjukkan bahwa luaran arus listrik dari dua buah panel surya yang dirangkai dengan sistem paralel untuk mengisi daya baterai 12 volt $45 \mathrm{AH}$ (baterai yang digunakan adalah baterai pada penelitian sebelumnya) dan terhubung pada sebuah motor listrik 50 watt, jika motor listrik tersebut dikoneksikan ke baterai, maka motor listrik akan terus bergerak rotasi dari jam 10.00 WIB hingga jam 15.30 WIB (selama 5 jam 30 menit), jika dibandingkan dengan kondisi dimana baterai 12 volt 45 AH yang sama pada penelitian seblumnya digunakan dalam keadaan tidak terhubung ke panel surya (kondisi baterai tidak 
terisi daya oleh panel surya), maka motor listrik hanya mampu bergerak putar rotasi dari jam 10.00 WIB hingga jam 12.15 WIB (selama 2 jam 15 menit). Hal tersebut jika dilihat dari data penelitian sebelumnya [11] relatif memiliki pola yang sama dalam hal besaran luaran arus listrik yang dikeluarkan oleh panel surya dimana terlihat pada Gambar 6 untuk grafik uji pengisian daya baterai yang dilakukan 3 kali pengujian, arus listrik relatif stabil pada range $200-600 \mathrm{~mA}$ dari pukul $09.00-16.00 \mathrm{WIB}$, terkecuali dari pukul $11.00-$ 14.00 daya baterai ketika di isi oleh dua panel surya mengalami fluktuasi.

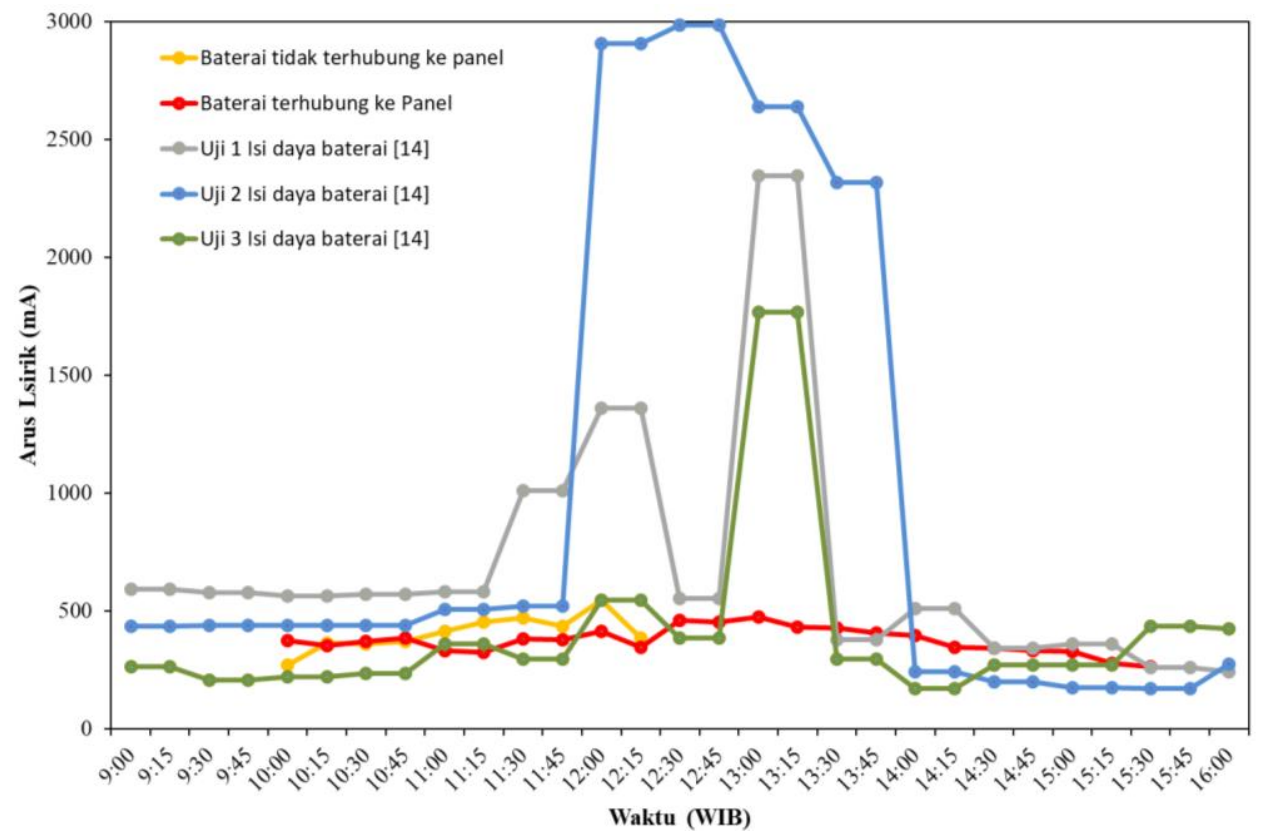

Gambar 6. Perbandingan luaran arus baterai kondisi terisi daya dan kondisi menggerakkan motor listrik

\subsection{Baterai Terhubung ke Motor Listrik dan Panel Surya Tidak Terhubung}

Performa motor listrik untuk terus hidup dan berputar tanpa pembebanan baik secara terhubung maupun tidak terhubung ke panel surya, tergambarkan pada grafik yang ditunjukkan pada Gambar 7 Penelitian ini menggunakan baterai yang digunakan pada penelitian sebelumnya.

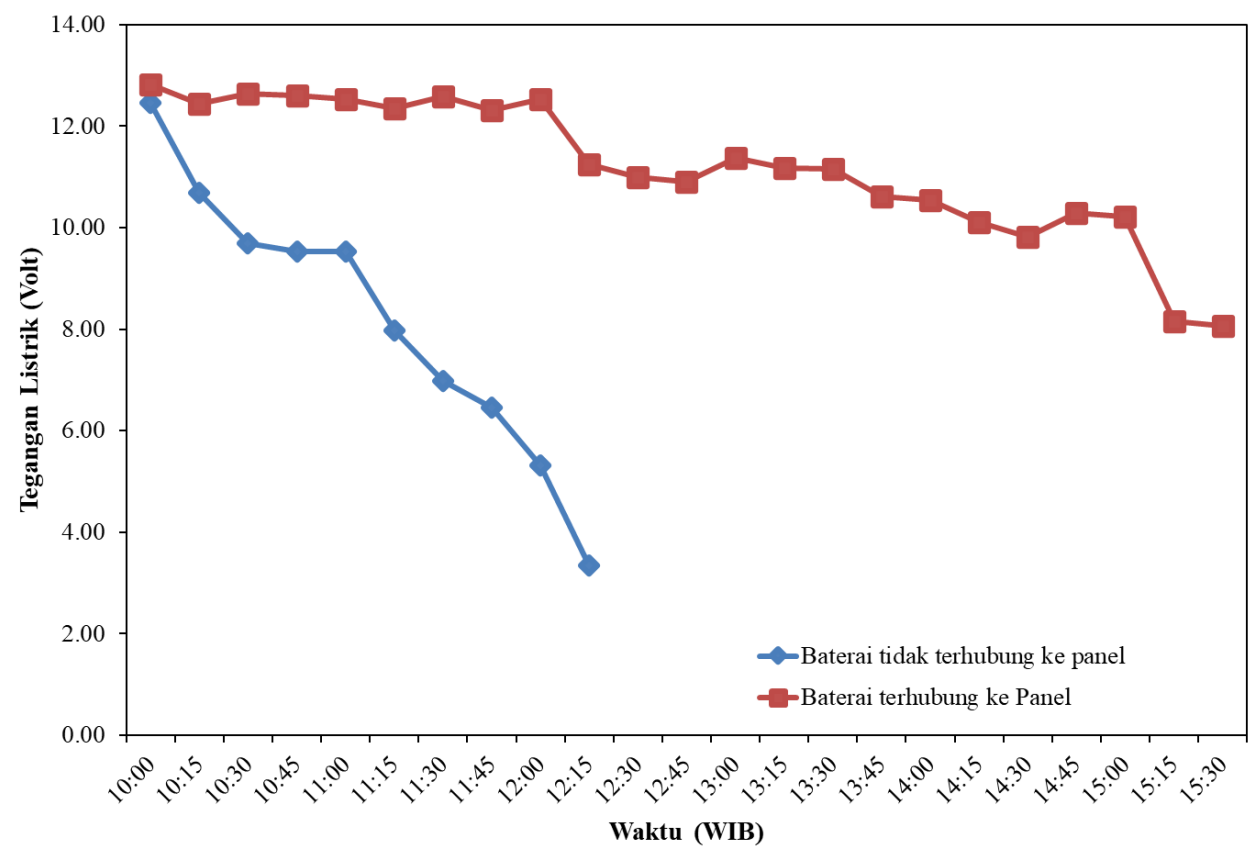

Gambar 7. Perbandingan tegangan luaran baterai untuk menggerakkan motor listrik 
Gambar 7 Menunjukkan bahwa jika motor listrik dengan daya 50 watt dihidupkan dengan menggunakan baterai 12 volt $45 \mathrm{AH}$ tanpa menggunakan panel surya (panel surya tidak terhubung ke baterai), maka motor listrik akan mampu hidup dan berputar hingga 2 jam 15 menit dengan luaran tegangan listrik terus menurun mengikuti waktu dan motor listrik berhenti bergerak pada tegangan sekitar 3,5 volt, tetapi jika baterai terhubung dengan panel surya yang berjumlah dua unit maka motor listrik akan mampu bekerja dan hidup hingga 5 jam 30 menit. Dengan tegangan relatif stabil dari pukul 10.00-12.00 WIB dengan tegangan rata-rata 12,5 volt dan motor listrik akan berhenti bergerak hingga pukul 15.30 WIB pada tegangan sekitar 8 volt.

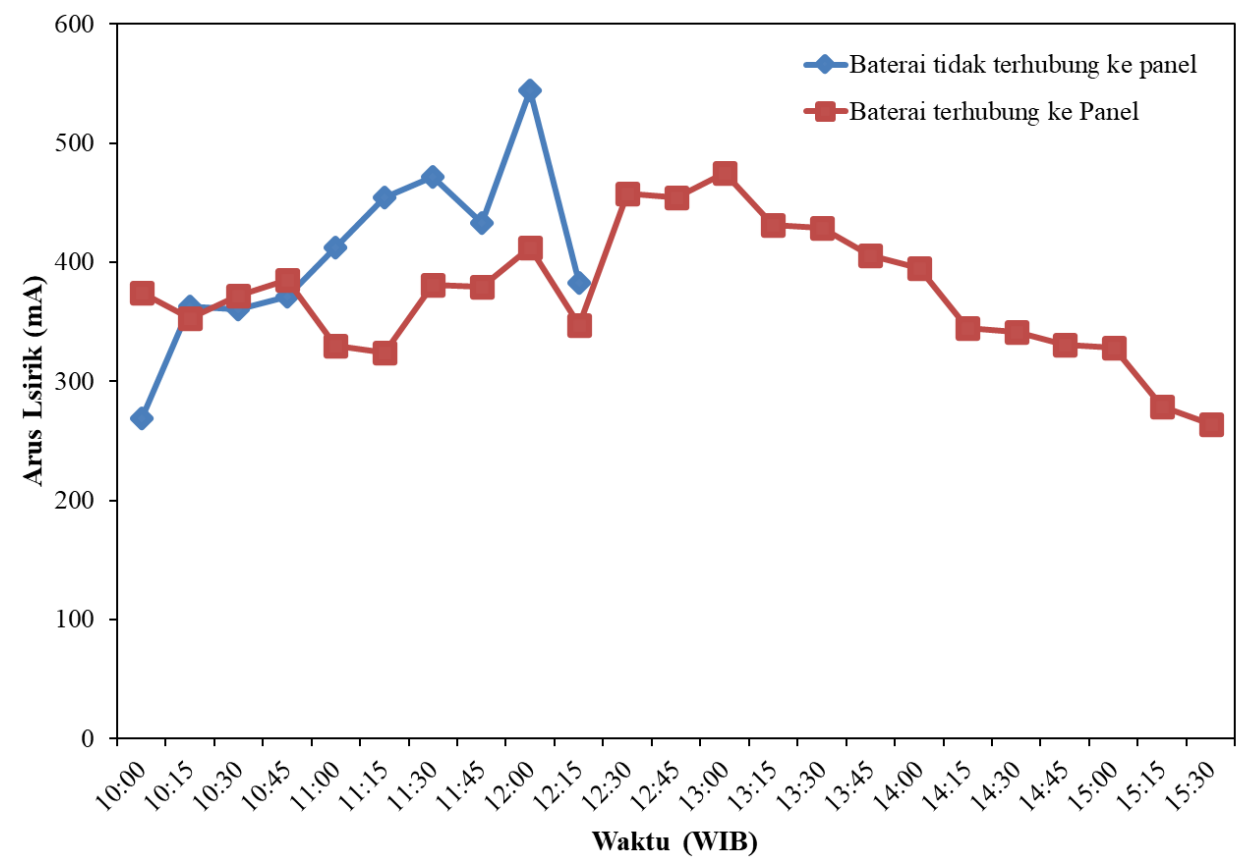

Gambar 8. Perbandingan arus luaran baterai untuk menggerakkan motor listrik

Kondisi luaraan arus listrik untuk kondisi baterai yang terhubung dan tidak terhubung ke baterai juga mengalami hal yang sama dimana arus listrik untuk kondisi baterai yang tidak terhubung ke panel surya, arus listriknya tiba-tiba akan terputus setelah 2 jam 15 menit berputar secara tiba-tiba, dan ini berbeda dengan kondisi dimana baterai jika terhubung ke panel surya dimana arus listriknya akan naik hingga pukul 13.00 WIB dan akan turun hingga pukul 15.30 WIB, kondisi ini ditunjukkan pada Gambar 8 Dimana arus listrik untuk kondisi baterai tidak terhubung ke panel surya maka motor listrik akan berhenti bergerak pada arus listrik $347 \mathrm{~mA}$ dan jika baterai terhubung ke panel surya dan baterai menggerakkan motor listrik dan bersamaan juga baterai di isi dayanya oleh panel surya, maka motor listrik akan berhenti bergerak pada arus listrik berada pada posisi $264 \mathrm{~mA}$. Dapat dikatakan bahwa motor listrik dapat bergerak rotasi pada arus lebih rendah jika baterai yang menggerakkan motor listrik dalam waktu bersamaan di isi dayanya oleh panel surya.

\subsection{Hubungan Tegangan dan Arus Luaran Panel Surya dan Baterai Terhubung ke Motor Listrik}

Secara umum dari data grafik yang ditunjukkan pada Gambar 9 setelah dilakukan analisis dari grafik memperlihatkan bahwa arus listrik relatif stabil dari awal hingga akhir baik ketika motor listrik mulai dihidupkan dan berputar rotasi, hingga motor listrik mati dan tidak keadaan berputar rotasi dan juga terlihat penurunan arus listrik selama pemakaian relatif kecil dan tidak signifikan.

Grafik juga menunjukkan bahwa tegangan luaran dari baterai 12 volt $45 \mathrm{AH}$ mengalami penurunan secara kontiyu dari pertama hidup hingga motor listrik berhenti berputar rotasi. Penurunan tegangan luaran dari baterai berbanding lurus terhadap waktu, kondisi tersebut tergambarkan pada Gambar 9. 


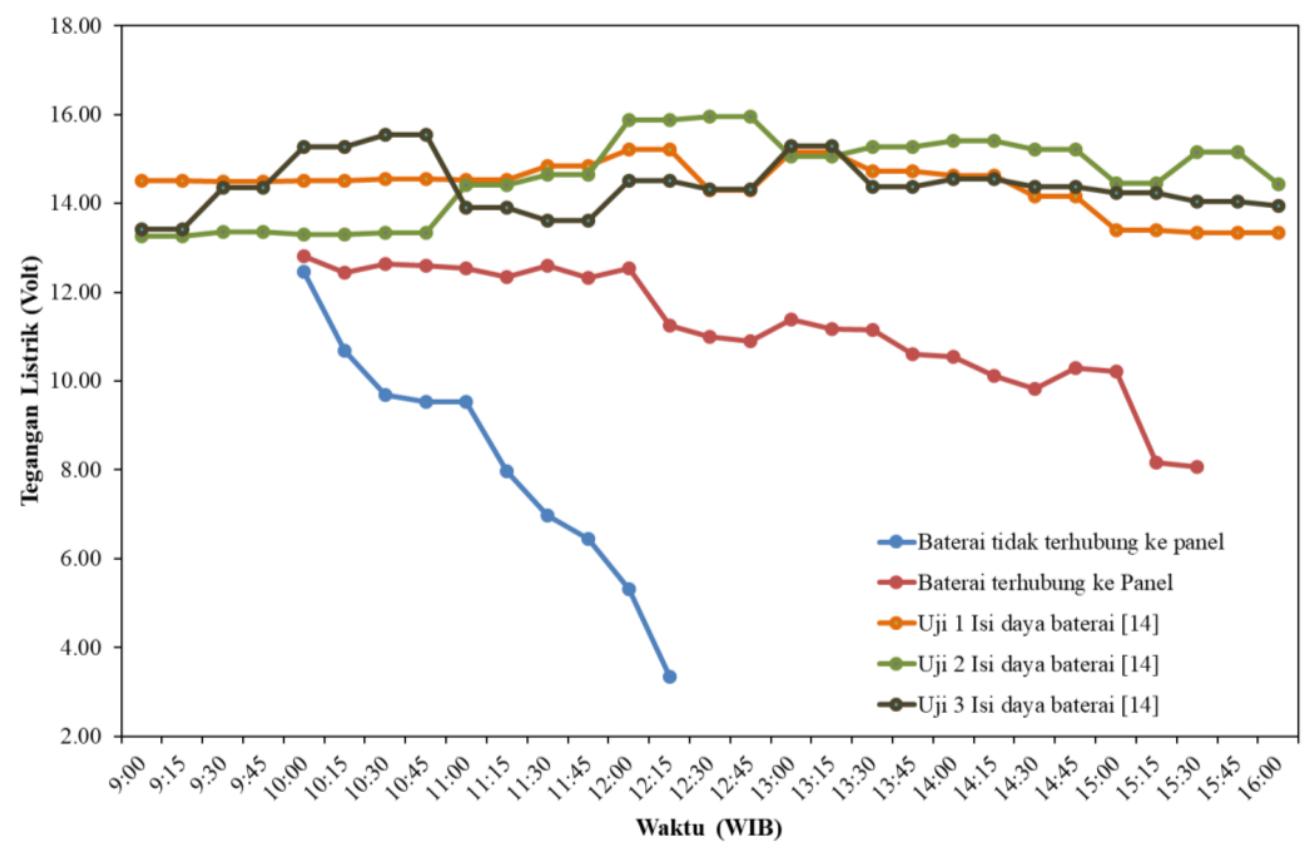

Gambar 9. Perbandingan luaran tegangan motor listrik kondisi terhubung dan tidak terhubung ke panel surya

Hasil uji kemampuan kerja baterai 12 volt 45 AH (baterai baru dan baterai yang digunakan pada penelitian sebelumnya) untuk menggerakkan motor listrik DC 50 watt, ditunjukkan pada Gambar 10.

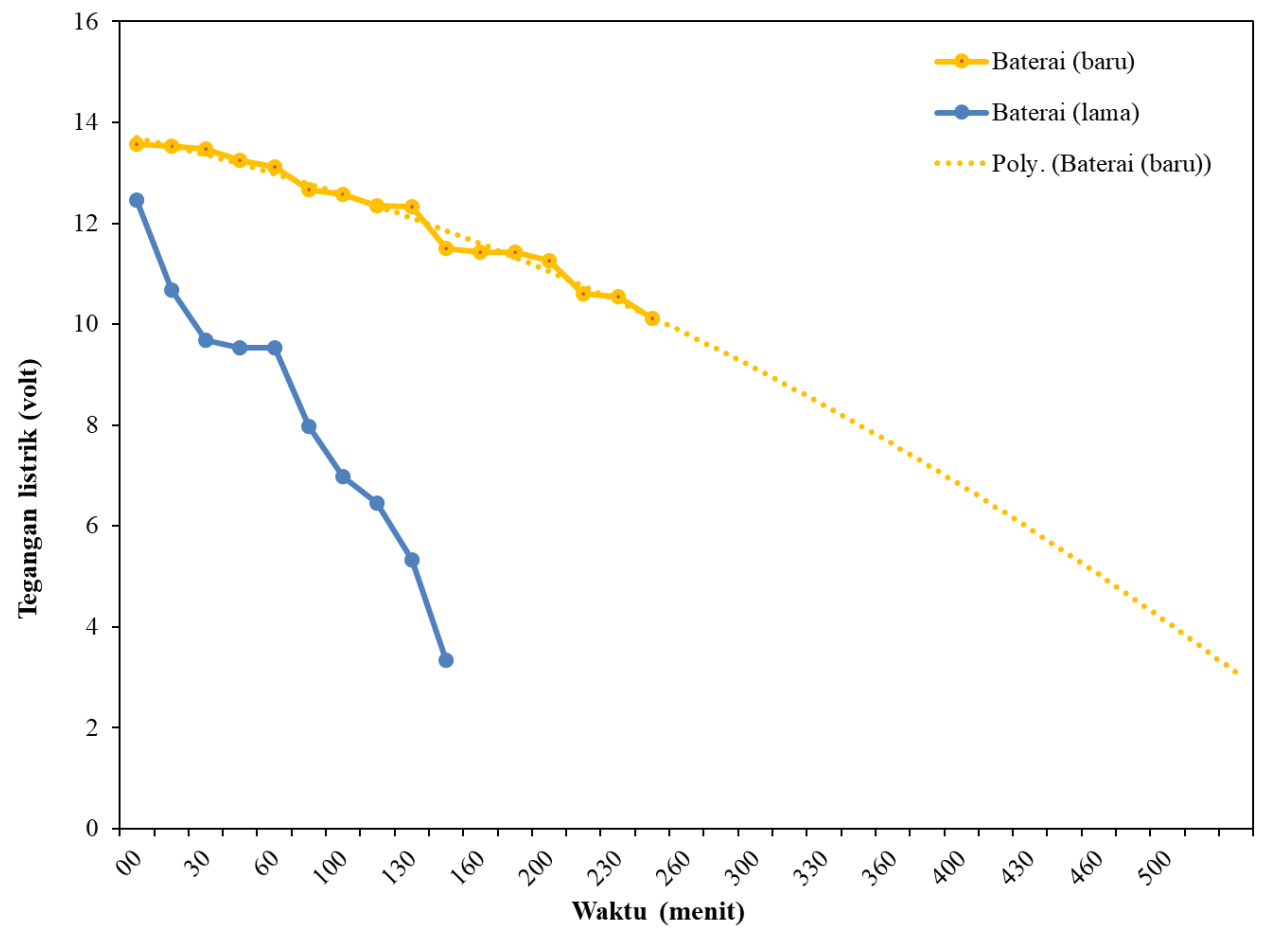

Gambar 10. Uji kemampuan baterai umur dua tahun dan baterai baru untuk menggerakkan motor listrik

Performa baterai baru dengan baterai yang digunakan pada penelitian sebelumnya ditunjukkan pada Gambar 10 Bahwa performa baterai baru hingga 245 menit motor listrik masih hidup dan bergerak rotasi dan diperkirakan motor listrik akan terus bergerak rotasi hingga lebih dari 8 jam ( $>500$ menit ). Umur pemakaian baterai berpengaruh terhadap performa baterai itu sendiri, dari Gambar 7 juga ditunjukkan bahwa baterai yang digunakan pada penelitian sebelumnya akan mampu menggerakkan motor listrik hingga 2 jam 15 menit, ini berarti performa baterai akan turun lebih dari $300 \%$. Kondisi ini disebabkan oleh penerimaan 
muatan listrik kehilangan kapasitas pada proses pengisian daya ke baterai, karena beberapa komponen baterai lead-acid mengalami kerusakan, yang disebut dengan fenomena premature capacity loss [18]

\section{KESIMPULAN}

Hasil penelitian kondisi pertama yaitu panel surya terhubung ke baterai dan tidak terhubung ke motor listrik menunjukkan bahwa arus listrik menjadi lebih stabil ketika menggunakan baterai baru, jika dibandingkan dengan menggunakan baterai pada penelitian sebelumnya. Kondisi kedua yaitu panel surya terhubung ke baterai dan terhubung ke motor listrik menunjukkan performa mesin panen padi mini dua lajur meningkat 50\% jika dibandingkan dengan kinerja motor listrik menggunakan baterai yang tidak terhubung ke panel surya. Kondisi ketiga yaitu panel surya tidak terhubung ke baterai dan baterai terhubung ke motor listrik menunjukkan bahwa kinerja motor listrik meningkat hingga 300\% jika dibandingkan dengan hasil penelitian sebelumnya, diperkirakan motor listrik akan terus bergerak rotasi hingga 8-10 jam. Hasil penelitian dipengaruhi oleh jenis dan umur pakai baterai yang digunakan pada penelitian

\section{PERNYATAAN TERIMAKASIH}

Ucapan terimakasih kepada Lembaga Penelitian, Pengabdian Kepada Masyarakat dan Penjaminan Mutu Pendidikan Universitas Teuku Umar, dan Laboratorium Teknik Mesin Fakultas Teknik Universitas Teuku Umar atas bantuan dan fasilitas yang diberikan sehingga penelitian ini dapat terlaksana dengan baik.

\section{DAFTAR PUSTAKA}

[1] H. SUSANTO, "Desain dan Manufaktur Teknologi Tepat Guna Pedesaan." Bandar Publishing, Banda Aceh, p. 227, 2018.

[2] P. GAUTAM, G. RANGANEKAR, and D. KANKAM, "Design and Developement of Compact Solar Agricultural Harvester Using Quick Return Mechanism," Int. Res. J. Eng. Technol., vol. 6, no. 6, p. 286, 2019.

[3] MULE. AB. et al, "Design and Fabrication of Harvesting Machine," Int. Res. J. Eng. Technol., vol. 5, no. $1,2018$.

[4] H. SUSANTO, A. BAKAR, and S. SYUHADA, "Rancang Bangun Mesin Pemotong Padi Multifungsi," J. Mekanova Mek. Inov. dan Teknol., vol. 3, no. 1, 2017.

[5] H. SUSANTO, "Rancang Bangun Mesin Panen Padi Mini Dua Lajur dengan Motor Penggerak Tenaga Surya," Pros. Semnastek, 2018.

[6] T. GEBRE et al, "Design of Mechanical TEF Harvesting Machine," Int. J. Adv. Res. Sci. Eng., vol. 5, no. 5, pp. 522-530, 2016.

[7] G. A. TEFERA and H. K. ASCHENAKI, "Designing and Prototyping of Multi-Crop Solar Powered Harvester,” Int. J. Sci. Eng. Res., vol. 10, no. 6, p. 662, 2019.

[8] H. SUSANTO, S. ALI, and H. HANIF, "The Design of Flexible Rubber Tapping Tool with Settings the Depth and Thickness Control," in IOP Conference Series: Materials Science and Engineering, Apr. 2019, vol. 506, no. 1, doi: 10.1088/1757-899X/506/1/012002.

[9] H. SUSANTO, Z. HUSIN, and J. SUPARDI, "Modification of Two-lane Mini Rice Harvesting Machine," in Seminar Nasional Tahunan Teknik Mesin (SNTTM), 2019, pp. 1-6, [Online]. Available: http://prosiding.bkstm.org/prosiding/seminar/2019.

[10] H. SUSANTO and Z. HUSIN, "Laporan Akhir Penelitian Dosen Muda: Kajian Kebutuhan Daya Motor Penggerak Mesin Panen Padi Dua Lajur Bertenaga Matahari,” Meulaboh, 2019.

[11] H. SUSANTO, Z. HUSIN, A. SUTRIAN, and N. FITRIADI, "Analisa Luaran Tegangan dan Arus Listrik pada Rangkaian Panel Surya Mesin Panen Padi Mini,” J. Mekanova Mek. Inov. dan Teknol., vol. 6, no. 1, pp. 77-84, 2020.

[12] S. ALI and T. M. A. PANDRIA, "Penentuan Sudut Kemiringan Optimal Panel Surya Untuk Wilayah Meulaboh,” J. Mekanova Mek. Inov. dan Teknol., vol. 4, no. 1, 2019.

[13] H. SUSANTO and T. TARMIZI, "Desain Dasar Dan Pembuatan Mobil Listrik," J. Mekanova Mek. Inov. dan Teknol., vol. 2, no. 2, 2016.

[14] M. H. ALBADI et al., "Design of a $50 \mathrm{~kW}$ solar PV rooftop system," Int. J. Smart Grid Clean Energy, vol. 3, no. 4, p. 401, 2014. 
[15] S. T. BURHANUDDIN, "Kajian Eksperimental Mesin Pendingin Adsorpsi Tenaga Surya dengan Menggunakan Adsorben Campuran," Rekayasa Mesin, vol. 10, no. 1, pp. 45-52, 2019.

[16] A. I. RAMADHAN, E. DINIARDI, and S. H. MUKTI, "Analisis desain sistem pembangkit listrik tenaga surya kapasitas 50 WP," Teknik, vol. 37, no. 2, pp. 59-63, 2016.

[17] A. ASTRADA, S. SOEPARMAN, and M. HAMIDI, "Pengaruh Pelat Penyerap terhadap Kinerja Solar Still di Kota Ngabang," Rekayasa Mesin, vol. 11, no. 1, pp. 85-95, 2020.

[18] A. F. HOLLENKAMP, K. K. CONSTANTI, A. M. HUEY, M. J. KOOP, and L. APUTEANU, "Premature capacity-loss mechanisms in lead/acid batteries," J. Power Sources, vol. 40, no. 1, pp. 125136, 1992, doi: https://doi.org/10.1016/0378-7753(92)80044-C. 